\title{
Pungente Vislumbre:
}

\section{A Triste Infalibilidade Da Culpa}

\author{
A pungent glimpse: the sad infallibility of guilt
}

\section{Thales Augusto Barretto de Castro}

\begin{abstract}
O$ crime do professor de matemática, by Clarice Lispector, addresses the unconscious need for punishment arising from the feeling of guilt, which is an inexorable element of the human psyche. The man's mirroring in his pet leads him to an approximation of a possible awareness of this disorder, which culminates in the unavoidable abandonment of the dog. Based on Sigmund Freud's essays Das Unheimliche and Das Unbehagen in der Kultur, we aim at understanding the origin of the doleful identification between these two characters in the narrated story, as well as the corollary of the culture that is responsible for the human sadness which the teacher is inevitably part of.
\end{abstract}

Keywords: uncanny, double, guilt, Clarice Lispector.

Resumo: $O$ crime do professor de Matemática, de Clarice Lispector, aborda a necessidade inconsciente de punição advinda do sentimento de culpa, que constitui elemento inexorável da psique humana. $\mathrm{O}$ espelhamento do homem em seu animal o conduz à aproximação de uma possível consciência deste transtorno, fato que culmina no irremissível abandono do cão. Com base nos ensaios $O$ estranho e $O$ mal-estar na civilização, de Sigmund Freud, almeja-se entender a origem da dolente identificação entre estes dois personagens narrada no conto, bem como o corolário da cultura, responsável pela tristeza humana com a qual o professor irremediavelmente se coaduna.

Palavras-chave: estranho; duplo; culpa; Clarice Lispector.

Zusammenfassung: In $O$ crime do professor de matemática von Clarice Lispector geht es um das unbewusste Bedürfnis nach Strafe, das von dem Schuldgefühl herrührt, welches ein unerbittlicher Teil der menschlichen Psyche ist. Die Spiegelung des Mannes in seinem Haustier bringt ihn einem möglichen Bewusstwerden dieser Störung näher, was in den unvermeidlichen

\footnotetext{
* O autor é mestrando na área de Língua e Literatura Alemã da Universidade de São Paulo e atualmente é bolsista CAPES. Endereço eletrônico: thalesabcunp@yahoo.com.br
} 
Barreto de Castro, T. A. - Pungente Vislumbre

Verzicht auf den Hund gipfelt. Basierend auf Sigmund Freuds Essays Das Unheimliche und Das Unbehagen in der Kultur wollen wir sowohl den Ursprung der schmerzvollen gegenseitigen Identifizierung der beiden Figuren dieser Erzählung verstehen als auch die Auswirkungen der Kultur, die für die menschliche Traurigkeit verantwortlich ist, von der der Lehrer unweigerlich ein Teil ist.

Stichwörter: unheimlich; Doppelgänger; Schuld; Clarice Lispector.

\section{Introdução}

Atualmente, vê-se que as contribuições da interface entre a literatura e a psicanálise têm suscitado interpretações cada vez mais vanguardistas de textos literários e podem ser apuradas em vários trabalhos acadêmicos nos quais a segunda funciona como aporte teórico para o estudo e aprofundamento das relações semânticas da primeira. Essas leituras baseiam-se em diversas correntes psicanalíticas, que promovem novos e impensados vínculos entre - por assim dizer - a arte e a ciência. Como se sabe, esse ramo do conhecimento científico - que concebe o ser humano para além do biológico tem sua consagração estreitamente vinculada àquele que é comumente definido como o “pai” da psicanálise: o austríaco Sigmund Freud (1856-1939).

A relação simbiótica entre literatura e psicanálise, diga-se, decorre historicamente das próprias investigações de Freud, que passou a demonstrar interesse pelas artes literárias enquanto objeto de problematização da consciência humana, utilizando-se de estórias e mitos como ponto de partida para discorrer sobre suas descobertas e hipóteses científicas - por exemplo, o "complexo de Édipo", derivado do personagem homônimo da tragédia de Sófocles (496 a 406 a.C, aprox.), um caso notório da relação mencionada acima entre a literatura e o estudo da mente.

Destarte, partindo do movimento contrário a este - isto é, da perspectiva da teoria freudiana para a análise de uma obra literária - discorre o presente estudo que, entre as reflexões propostas, elege a psicanálise como seu elemento norteador, embasado especialmente por dois ensaios de Freud - O estranho (edição de 1969; título original: Das Unheimliche) e O mal-estar na civilização (edição de 1997; título original: Das Unbehagen in der Kultur).

Do primeiro, abordamos a questão do duplo, bem como a vinculação da noção do estranho ou do "insólito" a algo que outrora fora familiar - sentimento paradoxal 
Barreto de Castro, T. A. - Pungente Vislumbre

advindo de um processo de repressão. Do segundo, interessa-nos a constatação, em especial, de um antagonismo intransponível entre as exigências da pulsão e da civilização - conflito que acarreta este "mal-estar" no chamado homem moderno. A especificidade e o desdobramento desses conceitos serão elucidados no decorrer deste ensaio, sendo oportunamente relacionados ao objeto literário que escolhemos para sua utilização: o conto $O$ crime do professor de matemática, de Clarice Lispector, que retrata o "drama" de um protagonista, caso oportuno para a convocação das principais ideias freudianas expostas nestes dois textos.

Além de nossa hipótese interpretativa, há outros estudos do texto de Lispector também sob a ótica da psicanálise, cujo tratamento, vale considerar, pauta-se em outro momento do percurso do mestre austríaco, como mostram ARRUDA FILHO (2003) e MARTINS (1996). Assim como no primeiro trabalho citado, tratamos da problemática do olhar, mas a partir de outro enfoque, como se verá. Do segundo, utilizamos a sugestão de também tratar o aspecto simbólico do conto, visto ser ele tão presente e facilmente depreensível da consciência do narrador; entretanto, nossa leitura segue um caminho diverso da interpretação daquele autor, atribuindo outros sentidos ao espaço em que se desenrola a trama.

A abordagem aqui proposta torna-se válida, então, devido a uma nova visada freudiana atribuída a esta narrativa já tão estudada. Assim, parafraseamos as ideias mais pertinentes ao objetivo de nossa proposição teórica, citando excertos dos textos de Freud que permitiram aproximações estéticas ao conto em questão - estética no sentido mesmo que aquele autor lhe atribui: "não simplesmente a teoria da beleza, mas a teoria das qualidades do sentir" (FREUD 1969: 85).

Desse modo, segue-se no próximo tópico a apresentação da narrativa - com o propósito de elucidação do que se pode chamar de "material de análise" -, a fim de promover a compreensão e a clareza deste entrelaçamento entre Freud e Lispector - e entre psicanálise e literatura, respectivamente - propostos neste estudo.

\section{Do cotidiano ao impulso artístico: a trama}

Inicialmente publicado no jornal carioca $A$ manhã, em 25 de agosto de 1946, com o título $O$ crime, sendo posteriormente enfeixado na coletânea Laços de Família - que 
consagraria Clarice Lispector definitivamente no panorama das letras nacionais -, $O$ crime do professor de Matemática possui relação direta com a vida pessoal da autora. $\mathrm{Na}$ contundente biografia escrita por Benjamin MosER, Why this world? (que, no título da tradução ao português - Clarice, uma biografia - perde a intrigante correspondência com as inquietações da escritora), há uma passagem que diz da gênese do conto - o desejo de Lispector se livrar do remorso causado pelo abandono de seu cão, Dilermando, quando de sua mudança para a Suíça. Em carta a uma de suas irmãs, expressou essa dor que a acompanhou para o além-mar:

Você sabe que revelação foi para mim ter um cão, ver e sentir a matéria de que é feito um cão. É a coisa mais doce que já vi, e cão é de uma paciência para com a natureza impotente dele e para com a natureza incompreensível dos outros... E com os pequenos meios que ele tem, com uma burrice cheia de doçura, ele arranja um modo de compreender a gente de um modo direto. Sobretudo Dilermando era uma coisa minha que eu não tinha que repartir com ninguém. (LISPECTOR, apud MOSER, 2011: 287)

A partir do estabelecimento dessa relação tão estreita, no caso em questão, entre vida e obra de Clarice Lispector, segue-se nas linhas abaixo um resumo, brevemente comentado, do enredo da narrativa, a partir do qual, nos tópicos que o seguem, visamos estabelecer sua aproximação ao embasamento teórico freudiano mencionado acima.

O professor de matemática, protagonista da estória, sobe uma colina com um cachorro morto dentro de um saco, a fim de enterrá-lo. Esse ritual é feito por ele como uma maneira paliativa de expiar a culpa sobrevinda da renúncia ao seu verdadeiro cão, José, quando de sua mudança de cidade. Já no alto da colina, cujo "ar fresco era inóspito" (LISPECTOR 2009: 118) ${ }^{1}$ - de onde se viam católicos seguindo para a missa de domingo -, o metódico professor, preocupado em "determinar rigorosamente o meio da chapada" (120) em que enterraria "o outro" animal, inicia, por assim dizer, sua epopeia.

À ideia da iminente consumação do ato, acumulam-se flashes que o levam a uma espécie de delírio rememorativo, que se intensifica assim que o cachorro "estranho" jaz debaixo da terra. Dessa feita, visto que "seu crime fora punido e ele estava livre" (121), põe-se a pensar no verdadeiro cão, afrouxando um pouco suas pungentes amarras, permitindo-se a um fluxo pulsante de pensamentos, que, no entanto, afetam-no de modo

\footnotetext{
${ }^{1}$ A partir deste ponto, todas as citações deste texto de Clarice Lispector serão indicadas apenas pela página, conforme o seguinte exemplo: (119). As demais citações seguem o modelo padrão.
} 
Barreto de Castro, T. A. - Pungente Vislumbre

a causar-lhe diversas sensações incompatíveis, advindas da relação singular entre esses dois seres - especialmente do espelhamento de si que o homem costumava vivenciar no animal. Essa profunda reflexão promove uma catarse que culmina no reconhecimento da impossibilidade de castigo para tal abandono. "Porque eu sabia que esse seria um crime menor e que ninguém vai para o Inferno por abandonar um cão [...] esse crime não era punível" (124).

Desse modo, diante do enterro simbólico de sua fraqueza, o matemático, assumindo sua falha, desenterra o cão - por consternada constatação da invalidade desta punição infligida a si mesmo, que, por sua vez, provém do sentimento que se revela a mola propulsora do conto: a culpa. Ao desenterrá-lo, portanto, "renovara o seu crime para sempre" (125). Ao final, ele opta por recorrer à sua família, onde certamente seria melhor compreendido e supostamente estaria imune a tais sensações "estranhas".

Assim, conforme se pôde observar, o conto trata, a priori, de um crime - o abandono de José, cão do professor de matemática. Desse modo, iniciamos nossa investigação pensando de que modo os resquícios inconscientes dessa relação homem/cão fazem com que o protagonista queira expiar sua incômoda culpa. Aliás, qual seria, de fato, essa culpa? O que o homem realmente abandonou, qual o abandono que o cão, em certo sentido, apenas representa simbolicamente? É o que se pretende demonstrar a seguir.

\section{$3 \bigcirc$ estranho}

O animal denunciava no homem aquilo de mais primitivo e recôndito, que este - pela sua escolha de um modo "matemático" de viver - reprime ao sucumbir a certo devir de tal profissão, baseado em expectativas e preceitos específicos, curvando-se metodicamente a ditames sociais e morais. Portanto, o bicho, que lhe causava uma sensação assaz incômoda, "estranha”, despertando-lhe para dolorosas reminiscências outrora recalcadas - deveria ser, de algum modo, necessariamente abandonado. Nesse ponto, apoiamo-nos no texto de Freud, $O$ estranho, para prosseguir nossa interpretação.

Para o estudo desse tema, Freud, a fim de confirmar sua hipótese de que "o estranho é aquela categoria do assustador que remete ao que é conhecido, de velho, e há muito familiar" (FREUD 1969: 87), baseia-se primeiramente na investigação e 
compilação de uma série de ocorrências individuais; em seguida, parte para o exame linguístico do uso da palavra heimlich. No ensaio em questão, porém, opta pelo caminho oposto, iniciando sua exposição pelo percurso etimológico.

Em princípio, a palavra é elucidada em diversas passagens, incluindo excertos de dicionários de língua latina, grega, inglesa e francesa. A minuciosa exposição adquire progressivamente, através de inúmeros exemplos, novas gradações de significado, de modo que heimlich (caseiro, familiar, agradável, oculto da vista) acaba por coincidir com seu oposto, unheimlich (estranho, "infamiliar", assustador), em que o prefixo de negação "un” revelaria o sinal da repressão. Em outras palavras: uma sensação que para nós outrora fora familiar - posteriormente sendo reprimida por algum processo psicológico complexo - torna-se estranha e incômoda ao retornar à consciência, mesmo que ainda não claramente definível. A estranheza, então, adviria do retorno em si, isto é, dessa ignota familiaridade com o fenômeno.

O termo permite ainda traduções interessantes ao português como "funesto", "sinistro", "esquerdo"; esta última tem especial significação para a presente análise como se verá adiante -, já que, conforme bem pontuou TAVARES (2007:11), em um prefácio de fôlego sobre o tema, "esquerdo [...] sugere visualmente que algo que faz parte de nós, é a metade nossa, mas ainda sim é visto como um lado cego, reprimido, a quem não é permitido tomar a iniciativa, manejar instrumentos etc."

No entanto, entendemos que unheimlich não encontra um vocábulo correspondente em outra língua de equivalente riqueza semântica e formal, pois seu sentido é tão ambivalente que se torna inexprimível, já que "a palavra nem sempre é usada num sentido claramente definível, de modo que tende a coincidir com aquilo que desperta o medo em geral" (FREUD 1969: 86). Essa falta reflete-se no próprio entendimento da experiência do estranho, visto tratar-se de um sentimento que não se consegue delinear com clareza. No trajeto esboçado no ensaio de Freud, em que heimlich chega a coincidir com o seu oposto unheimlich, há a seguinte definição do dicionário de SANDERS (apud FREUD 1969: 89), interessante ao nosso estudo na medida em que contribui para o entendimento de como essa dúbia sensação - que progressivamente transforma o familiar em estranho - pode caracterizar a relação do professor com seu cão: 
(b) De animais: domesticado, capaz de fazer companhia ao homem. Em oposição a selvagem, e.g. 'Animais que não são selvagens nem heimlich', etc. 'Animais selvagens... que são educados para serem heimlich e acostumados ao homem.' 'Se essas jovens criaturas são criadas desde os primeiros dias entre os homens, tornam-se bastante heimlich, amistosas etc. - Assim também: '(O cordeiro) é tão heimlich e come na minha mão.' 'Não obstante, a cegonha é um belo heimlich passáro", 2

Nota-se nesses exemplos o quão flutuante pode ser a definição do conceito, significando no caso acima tanto "doméstico" quanto "não domesticado". De que modo, então, despertaria José - um animal já domesticado - sensações incômodas e dificilmente definíveis no professor de matemática, de modo que os papéis se invertam, culminando em certa animalização do homem? Esse aspecto será melhor desenvolvido no último tópico.

Há de se mencionar também que o uso hodierno da palavra heimlich na língua alemã perdeu várias das significações elencadas na exposição feita por Freud, sendo a correspondência a "escondido" ou "fora da vista" mais condizente com o contexto atual; essa conjuntura, entretanto, não compromete a importância do estudo, já que uma possível definição do sentimento do estranho está além de sua analogia ao trajeto etimológico esboçado no artigo.

$\mathrm{Na}$ segunda parte do ensaio, Freud recorre à literatura fantástica para aprofundar a explanação do conceito de unheimlich, analisando o conto $O$ homem da areia de E.T.A. HOFFMANN (1776-1822), ao qual atribui "uma inigualável atmosfera de estranheza" (FREUD 1969: 95), sendo por ele eleito como o principal tema do conto, o fato de o homem da areia arrancar os olhos das crianças. Nesse sentido, atribui ao medo de ter os olhos feridos ou mesmo arrancados o temor de ser castrado, funcionando aquele como simples paliativo deste. Essa analogia, porém, não será referida aqui.

Se formos à palavra alemã, a sensação de algo "outro" ou "estranho" é intensificada pelo gênero do substantivo em questão, imprimindo novas nuances à análise de nosso objeto de estudo. O das de Das Unheimliche é definição ausente no universo feminino e no masculino, ele é neutro, portanto, dificilmente tangível, referencializável. Interessante pensar, desse modo, em como seria concebida a ideia

\footnotetext{
${ }^{2}$ Esta mistura entre português e alemão na tradução do texto de Freud permeia toda a exposição que visa esclarecer os usos - e significados - desta palavra. Nota-se que ela pode causar certa dificuldade para o leitor de língua portuguesa; ainda assim, no entanto, uma possível tradução para o termo - além de insuficiente - poderia desviar o foco da ambivalência do mesmo, a qual, como sabemos, é presente apenas no original alemão.
} 
"estranha" da existência de um nome neutro na concepção de um leitor brasileiro, já que não possuímos tal artigo em nossa língua. Somos remetidos, portanto, ao âmbito do "it" (ou “es" em alemão), aquilo que não se pode definir - “o indizível” -, tão presente nos escritos clariceanos, especialmente em Água Viva, obra publicada em 1973.

$\mathrm{Na}$ sequência, demonstrar-se-á de que modo esse sentimento do estranho permeia o conto de Lispector, ressaltando a abrangência do olhar na constituição do crime do professor.

\section{4. $\bigcirc$ pungente vislumbre}

Tema caro à literatura psicanalítica, o olhar tem sido objeto de inúmeros estudos pósfreudianos. Para além daquela relação de equivalência proposta por Freud (mencionada acima) - entre o falo e o olho -, o olhar é tido como principal elemento constitutivo dos processos psíquicos do sujeito, sendo o primeiro objeto de desejo do bebê. Conforme QUEIROZ (2005: 89-100), a maneira como somos olhados define nosso modo de conceber o mundo já que o nosso pensamento se constitui por meio de imagens ópticas. Olhar é pensar. Pode ser ora abrangente, ora incisivo. No ato de olhar estão implícitos, simultaneamente, inteligência e sentimento.

O sujeito, ao mesmo tempo em que o deseja, torna-se seu alvo, sendo, assim, afetado por ele: “Às vezes, sentado sobre as patas diante de mim, como me espiavas! Eu então olhava o teto, tossia, dissimulava, olhava as unhas, [...] mas nada te distraía: tu me espiavas. Tolo que eu era. Eu fremia de horror [...]" (123).

No conto, a cumplicidade que culmina na identificação entre o professor e o cão torna-se, com o passar do tempo, mais intensa e dolorosa - o fato de o homem ver no seu animal um espelho que mostra além da imagem, da superfície, começa a despertá-lo para revelações indesejadas. Seu caráter era escuso e assim ele o preferiria manter - era mais cômodo e mais condizente com suas escolhas. No entanto, inevitavelmente, desse conflito direto e desagradável emerge uma inquietação humana existencial: "porque, embora meu, nunca me cedeste nem um pouco do teu passado e de tua natureza" (122). Tal agonia remete a uma - por assim dizer - "máxima" clariceana: "como viver sem pertencer?". 
Às vezes, tocado pela tua acuidade, eu conseguia ver em ti a tua própria angústia. Não a angústia de ser cão que era a tua única forma possível. Mas a angústia de existir de um modo tão perfeito que se tornava uma alegria insuportável: davas então um pulo e vinhas lamber meu rosto com amor inteiramente dado e certo perigo de ódio como se fosse eu quem, pela amizade, te houvesse revelado. Agora estou bem certo de que não fui eu quem teve um cão. Foste tu que tiveste uma pessoa (123).

Essa passagem é uma das várias outras em que a projeção do homem no cão remete-nos necessariamente a outra categoria presente no ensaio de Freud, também permeada pelo sentimento de estranheza - o duplo. O duplo perturba o ego,

\begin{abstract}
assim, temos personagens que devem ser considerados idênticos, porque são semelhantes, iguais. Essa relação é acentuada por processos mentais que saltam de um para outro desses personagens - pelo que chamaríamos de telepatia -, de modo que um possui conhecimento, sentimentos e experiência em comum com o outro. Ou é marcada pelo fato de que o sujeito identifica-se com outra pessoa, de tal forma que fica em dúvida sobre quem é seu eu (self), ou substitui o seu próprio eu (self) por um estranho. Em outras palavras, há uma duplicação, divisão e intercâmbio do eu (self). (FREUD 1969: 123)
\end{abstract}

Nesse sentido, pode-se ler o conto como um jogo de espelhos entre os três personagens centrais - o professor de matemática, o cão verdadeiro (José) e o falso cão (morto). O primeiro desses casos, conforme já elucidado, seria a projeção do homem em José. Logo após concluir o ato ritualístico de enterro do falso cão "pôs-se a pensar com dificuldade no verdadeiro cão como se tentasse pensar com dificuldade na sua verdadeira vida" (121). Ou, ainda como exemplo, temos o professor descrevendo uma simples situação de troca de olhares com José: "tão pequeno, bonitinho e fraco, abanando o rabo, me olhando, e eu surpreendendo em ti uma nova forma de ter minha alma." (122) O personagem passa, então, a entrar em contato com seu próprio mundo interior, rememorando e criticando-se a si mesmo.

Dessa maneira, começa-se a compreender melhor a ligação tão forte entre o professor e José, sendo esse vislumbre de contornos tão pouco nítidos que, na própria narrativa, confundem-se os personagens - hipótese verificada na escolha do narrador pelo pronome "ele" no seguinte excerto - "mas se fosse o outro, o verdadeiro cão, enterrá-lo-ia na verdade onde ele próprio gostaria de ser sepultado se estivesse morto: no centro mesmo da chapada a encarar de olhos vazios o sol” (119). Quem seria esse "ele", o professor ou José? Aqui, portanto, além da intrincada voz do narrador 
corroborar a atmosfera de duplicação entre os personagens, teríamos o primeiro sinal da aflitiva alteridade entre o matemático e seu animal.

A segunda ocorrência do duplo dar-se-ia entre os cachorros - o cão abandonado e o cão morto. Aqui, conforme afirma o psicanalista vienense, amigo íntimo de Freud, Otto RANK (apud FREUD 1969: 103), o duplo pode ser entendido como uma "enérgica negação do poder da morte" no sentido de que o cão presente, mesmo que morto, reaviva o cão abandonado (de certa forma, portanto, também morto) na memória do professor e, para Freud, “a alma 'imortal' foi o primeiro 'duplo' do corpo” (FREUD 1969: 103).

E ainda, o espelhamento do matemático no animal substituto: "era um cão estranho e objetivo" (121) - adjetivos que se conformam à própria personalidade do professor, que se havia moldado "estranha e objetivamente", tendo sofrido, assim, uma "morte em vida", já que se tornara impassível diante de diversos sentimentos originais e primitivos que foram ocultados pelo processo de repressão (simbolizados linguisticamente pelo prefixo "un": heimlich - unheimlich). O narrador, ao justapor os adjetivos estranho e objetivo, quando do encontro em um passado próximo entre o professor e o cachorro morto, remete-nos novamente à metáfora do duplo: o cão objetivo é aquele que simultaneamente é estranho, já que morto - assim como a "verdadeira" personalidade do professor; José, o cão abandonado, ilustraria então a outra metade do professor - subjetiva - relegada aos escombros da mente.

Há ainda um número considerável de passagens em que somos reportados a esse intertexto freudiano. Já no início do conto - "sem os óculos, seus olhos piscaram claros, quase jovens, infamiliares" (118) -, fica clara a correspondência com o sentimento de estranheza discutido no ensaio. Note-se o trecho "quase jovens, infamiliares" (118). "Quase" remete a um período da vida do professor em que o processo de recalcamento ainda não o dominava por completo, isto é, fica claro que houve um momento anterior ao da mudança para a nova cidade em que o homem deixou de ser familiar a si mesmo, tornando-se "estranho", "não-familiar". O homem tira e novamente recoloca os óculos - sem eles "respirou muito fundo" (118) aproximando-se de seu âmago, como se os óculos permitissem uma visão mais objetiva, apolínea, "familiar", impedindo-o, simbolicamente, de sucumbir a um regresso ao mais profundo de si mesmo, protegendoo de encontrar as raízes de sua implacável culpa. 
A importância dos óculos em todo o processo de sepultamento do cão é novamente reiterada - ao colocar a mão no cachorro morto, no seu "outro", o professor está novamente sem os óculos e "mantinha os olhos profundamente fechados enquanto puxava" (119). É como se dolorosamente alcançasse, mesmo que por poucos instantes, o seu eu mais profundo, o seu subjetivo, isto é, uma característica primitiva banida da sua formação enquanto sujeito, a qual não consegue nem ao menos tanger através dos seus óculos sociais - ou olhos artificiais -, já que estes comprometem a abrangência de seu discernimento e não o permitem enxergar distintamente, mas sim restritamente. Seu olhar, portanto, começa a se ampliar, de modo a conceber o seu unheimlich.

No mesmo momento em que o homem busca amortizar essa dívida/culpa ${ }^{3}$, "os sinos alegres tocaram novamente chamando os fiéis para o consolo da punição" (119) consolo também buscado pelo homem, porém, em vão, pois, em seu caso, não há uma instituição detentora de poder que possa servir de testemunha para a redenção buscada, visto que esta é individual e habita "apenas" sua consciência. Assim como em uma rotineira visita dos católicos à igreja, para ele "tratava de dar ao acontecimento a fatalidade do acaso, a marca de uma ocorrência exterior e evidente" (120), sem que tal ato fosse suficientemente refletido - evitando assim a experiência de vivenciar uma incômoda transformação -, devendo permanecer na superfície, em estado de latência, já que se tratava de "expor-se e de expor um fato, e de não lhe permitir a forma íntima e impune de um pensamento." (120).

“O cachorro desconhecido estava à luz" (119). Reitera-se nessa passagem, não por acaso separada pelo narrador em um parágrafo isolado, a ideia do cão substituto como metáfora do recalcamento do professor - que hesita tenazmente em realizar o enterro simbólico do animal. Como no doloroso processo da análise, de novamente trazer à consciência sensações e sentimentos recalcados, o matemático, após retirar o cachorro morto do saco, “como se já tivesse feito muito, pôs os óculos, sentou-se ao lado do cão e começou a observar a paisagem" (119).

Revelador de toda a constituição do pensar-agir do protagonista é o campo semântico das expressões que aparecem sucessivamente durante o sepultamento do falso cão - procedimentos tão relacionados à lógica cartesiana de um professor de matemática -: "observou com precisão"; "para maior perfeição do ato"; "precisamente"; "com frieza"; “excesso de escrúpulo"; “determinar rigorosamente”, dentre outros que,

\footnotetext{
${ }^{3}$ Em alemão, o vocábulo Schuld possui ambas as significações.
} 
além de revelarem a tentativa de dar continuidade a um modo sistemático e objetivo de ser do professor, conotam também - e talvez isto seja primordial no entendimento desse modo de agir - a busca de um equilíbrio interno que, durante o ritual, foge ao seu tão rígido controle de si.

O ambiente escolhido pelo professor para se redimir de sua culpa permite-nos atribuir um sentido ainda maior aos seus procedimentos ritualísticos, devido às inúmeras conotações possíveis que ele enseja.

\section{Narrativa: Dualidade e Simbologia}

Em sentido diverso, temos outra dualidade: o foco narrativo, já que, a partir de determinado momento, o narrador-observador presente no início do conto dá voz ao protagonista, que se manifesta em um discurso em primeira pessoa, marcado pelas aspas. Trata-se de "um diálogo" no qual se dirige a José, que, no entanto, conforme se acredita aqui, pode ser pensado também como um monólogo, pois o professor estaria comunicando-se com o seu outro, aquela sua outra parte - que deveria ter ficado escondida, mas veio à luz (cf. FREUD 1969: 92).

A dualidade temporal também está presente na narrativa. $\mathrm{O}$ conto inicia-se no pretérito perfeito, que vai sendo mesclado ao imperfeito. Do mesmo modo, as impressões do narrador vão se misturando às do protagonista; assim, em determinado momento, o professor traz ao presente o passado, fato possível pelo uso da memória. Dessa mistura de vozes, a seguinte passagem é bastante ilustrativa:

\footnotetext{
Mas possuíste uma pessoa tão poderosa que podia escolher: e então te abandonou. Com alívio te abandonou. Com alívio sim, pois exigias - com a incompreensão serena e simples de quem é um cão heroico - que eu fosse um homem. (123).
}

O narrador onisciente se confunde com o personagem e este último distancia-se de si durante o processo rememorativo, tratando-se em terceira pessoa.

Considerando o plano da espacialidade, verifica-se a nítida diferenciação entre o alto ("chapada", "planalto", "colina mais alta") e o baixo ("a cidade embaixo", "os tetos irregulares das casas", "os católicos [...] na igreja"), que se configura como uma dicotomia singular/coletivo. Nesse sentido, digno de nota é o modo como o narrador 
refere-se às questões religiosas. O momento da grande revelação - epifânico - ocorre quando o professor de matemática está no alto, acima dos católicos que servem de testemunhas do seu ato - "todos são meus cúmplices, José” (124) -, isto é, no momento em que ele está geograficamente em cima, é que, metaforicamente, também se eleva, negando ao menos temporariamente os valores, crenças e costumes daqueles que estão embaixo.

Essas diversas referências ao discurso religioso - "católicos", "igreja”, "consolo da punição", "missa", "pecado" e mesmo o nome "José" - revelam uma crítica de fundo; a experiência a ser vivenciada no alto prescinde da divindade institucionalizada, o homem busca constituir-se enquanto sujeito na colina mais alta. Ao alcançá-la, então, distingue-se da massa humana entrando em bloco - como ovelhas - na igreja. A abrangência/importância desse ritual emerge pelo significado que pode ser atribuído ao espaço em que se encontra o matemático, visto que a colina

[...] é a primeira manifestação da criação do mundo: saliente o bastante para diferenciar-se do caos inicial, ela não tem a majestosa imensidade da montanha. Marca o começo de uma emergência e da diferenciação. Seus contornos suaves se harmonizam com o aspecto do sagrado que está na medida do homem. (CHEVALIER \& GHEERBRANT 2008: 264)

Nesse momento, então, o homem assemelha-se ao sagrado, que está, porém, em sua medida, isto é, não há o processo assimétrico tão comum no relacionamento entre a instituição religiosa e seus fiéis. A adesão a um sistema próprio, que revela outro caminho para sua redenção, é ainda corroborada simbolicamente pela presença da única árvore,

figura axial, ela é naturalmente o caminho ascensional ao longo do qual transitam aqueles que passam do visível ao invisível [...] É o pilar central que sustenta o templo ou a casa, na tradição judaico-cristã, e é também a coluna vertebral a sustentar o corpo humano, templo da alma, simbolizando ainda "aspecto cíclico da evolução cósmica: morte e regeneração" (CHEVALIER \& GHEERBRANT 2008: 84-85).

O professor, ao realizar a cerimônia fúnebre, busca o equilíbrio que viria a lhe proporcionar essa renovação. Desse modo, antes da consumação do fato, "pensou no lugar que escolheria. Talvez embaixo da árvore. Surpreendeu-se refletindo que embaixo da árvore enterraria este cão.” (119). No entanto, seu sobressalto não o conduz à libertação almejada, já que apesar da magnificência da árvore, o rio - que enseja o 
retorno ao princípio das coisas, o acesso ao Nirvana (cf. CHEVALIER \& GHEERBRANT 2008: 780-781) - está parado, obstando-o ao resgate de si.

Com isso, ficamos tentados a associar este malogro a alguma espécie de trauma que estaria mais profundamente arraigado na constituição do ego do professor; algo do passado de sua vida mental que não é passível de substituição e que esteja vinculado às suas tentativas frustradas de obter felicidade.

\section{Da culpa entristecida}

Conforme se pôde demonstrar acima, $O$ crime do professor de matemática diz muito de uma "ligação outra" entre homem e animal. O que a princípio se entende dessa relação aparentemente desnivelada entre o ser racional e o irracional, revela-se determinante na compreensão do eu mais profundo do professor. José, sendo apenas um cão, com seus traços puros de animal doméstico, com seu olhar insistente, como que recriminando o professor, exigia que este fosse apenas um homem, demonstrando-lhe e "dizendo-lhe" sem que, no entanto, tivesse a intenção de fazê-lo -, de sua natureza mutilada, deturpada pelo processo de recalcamento.

Dessa forma, o paralelo com o texto freudiano, $O$ estranho, contribui para uma primeira compreensão desse sentimento nostálgico do professor, que paga um alto preço pela civilização - em detrimento de seu desenvolvimento enquanto indivíduo. No entanto, a fim de compreender melhor essa "castração social" - o conflito entre o indivíduo e a sociedade -, retomamos outra fase do percurso das investigações freudianas que julgamos de grande pertinência para este estudo, quais sejam, aquelas discutidas em $O$ mal-estar na civilização. Conforme se depreende da leitura do conto de Lispector, o professor de matemática opta pelo abandono do cão, tido como empecilho em sua mudança de cidade. Entendemos esse ato como uma metáfora da opção do matemático pela integração à comunidade humana, à custa da anulação de si. Disso, então, surgiria seu maior infortúnio.

Para FREUD (1969) parece muito contraditória a constatação de que os regulamentos criados pelos próprios homens para lhes garantir proteção contra o sofrimento não representem benefícios para os mesmos. Destarte, conscientes do insucesso, devemos suspeitar de que "é possível jazer, por trás desse fato, uma parcela 
de natureza inconquistável - dessa vez, uma parcela de nossa própria constituição psíquica.” (FREUD 1969: 37).

Dessa sua hipótese deriva o argumento de que "o que chamamos de nossa civilização é em grande parte responsável por nossa desgraça e que seríamos muito mais felizes se a abandonássemos e retornássemos às condições primitivas" (FREUD 1969: 38). Esse retorno a um estágio de desenvolvimento psíquico há muito banido da consciência - "inconquistável” - ameaçava emergir novamente na consciência do professor através do contato com o seu cão, tornando-o consciente das possibilidades de felicidade há muito abandonadas em favor de seu desenvolvimento e confluência na sociedade, no mundo civilizado. Segundo o teórico, entende-se por civilização,

[...] a soma integral das realizações e regulamentos que distinguem nossas vidas das de nossos antepassados animais, e que servem a dois intuitos, a saber: o de proteger os homens contra a natureza e o de ajustar os seus relacionamentos mútuos (FREUD 1969: 41-42).

Essa proteção contra a natureza diz respeito, de um lado, às conquistas do homem desde os primeiros vestígios de civilização (por exemplo, o domínio do fogo; ou, mais adiante, a criação do navio, do automóvel e do avião contra as distâncias até então intransponíveis, etc.). De outro, temos o domínio do homem sobre a natureza dos seus instintos - condição primordial e indissociável da vida em sociedade - com a criação de regras, leis e direitos que viabilizem a convivência e a segurança na comunidade (FREUD 1969: 42-45).

Para Freud, consiste em amplo enleio o domínio do indivíduo sobre os seus instintos, de modo que este consiga esquivar-se do sofrimento. Ainda assim, acredita haver algumas saídas. Dentre elas, ocuparia importante espaço o trabalho, que, reorientando as pulsões da libido, justificaria e possibilitaria a existência humana em sociedade, sublimando de modo positivo (se voluntariamente) tais impulsos. Dessa constatação, cabe pensar de que modo teria o professor ${ }^{4}$ lidado com esses instintos e

\footnotetext{
${ }^{4}$ Parece-nos que a escolha de Lispector por definir o protagonista como um professor de matemática não é feita arbitrariamente, tendo em vista que, em geral, em oposição ao sentimento e a subjetividade, as ciências exatas não dão margem a interpretações ambíguas, sendo bastante "práticas" e inequívocas - em larga oposição ao ser humano. Nesse sentido, a título de curiosidade, lembremos aqui do professor do conto Os Desastres de Sofia que "passara pesadamente a ensinar no curso primário [...] de ombros contraídos" e "óculos sem aro" (LISPECTOR 1998: 98), que, da mesma forma que o matemático, parece não ter lidado bem com suas pulsões libidinais.
} 
quais outras circunstâncias civilizatórias influem no abandono do cão. Aliviado em deixar o perigo para trás, alicerça-se ainda na opinião da família, utilizando-se de

[...] uma desculpa que todos em casa aprovaram: porque como poderia eu fazer uma viagem de mudança com bagagem e família, e ainda mais um cão [...] 'Que não cabe em parte alguma', disse Marta prática. 'Que incomodará os passageiros', explicou minha sogra sem saber que previamente me justificava [...]" (p.124).

A incompatibilidade entre indivíduo e comunidade é condição inerente ao processo civilizatório. "O poder dessa comunidade é então estabelecido como 'direito', em oposição ao poder do indivíduo, condenado como "força bruta"” (FREUD 1969: 49). Logo, em favor da vida em sociedade, o professor restringe-se em suas possibilidades de satisfação. O animal representaria, nesse caso, uma metáfora de seus instintos, das suas possibilidades irrestritas de prazer; assim, o matemático, a fim de não incomodar "os outros" e fazer jus à lei da maioria, deve privar-se de ser feliz, optando pelo que é "seguro", em detrimento de sua liberdade de escolha.

Essa contenção dos instintos não é, entretanto, alcançada de maneira plácida; além da libido, ela compromete também a satisfação de outra característica intrínseca ao ser humano: a agressividade. Para Freud, são estes os dois grandes óbices ao desenvolvimento pacífico da civilização, ameaçando-a de desintegração caso não sejam devidamente controlados e/ou sublimados. A intimidação que o cão despertava no professor, advinda deste último instinto, intensifica seu incômodo, que irá corroborar também o inevitável abandono:

\footnotetext{
Ah, sim, eras irredutível: eu não queria que comesses carne para que não ficasses feroz, mas pulaste um dia sobre a mesa e, entre os gritos felizes das crianças, agarraste a carne e, com uma ferocidade que não vem do que se come, me olhaste mudo e irredutível com a carne na boca. (122)
}

Seu hábito de não dar carne para o animal, evitando que este ficasse agressivo, funcionava talvez como um reconforto, uma superstição falida, consequência provável de crenças populares, convenientes a certos procedimentos civilizatórios, que "sugerem" como domesticar um cão. Não obstante essa aleivosia, o professor torna-se cada vez mais consciente do caminho ao qual esse relacionamento inevitavelmente o conduziria. "Minha ferocidade e a tua não deveriam se trocar por doçura: era isso o que pouco a pouco me ensinava, e era isto também que se tornava pesado.” (122). 
O contraste entre docilidade e agressividade instintiva, seria, então, a maior e mais penosa revelação que o cão exortava em seu dono - através daquele processo de espelhamento visto acima. Freud estabelece deste conflito - aqui simbolizado por homem/animal - uma analogia para o instinto agressivo que

[...] é o derivado e o principal representante do instinto de morte, que descobrimos lado a lado de Eros e que com este divide o domínio do mundo. Agora, penso eu, o significado da evolução da civilização não mais nos é obscuro. Ele deve representar a luta entre Eros e Morte, entre o instinto de vida e o instinto de destruição, tal como ela se elabora na espécie humana. Nessa luta consiste essencialmente toda a vida, e, portanto, a evolução da civilização pode ser simplesmente descrita como a luta da espécie humana pela vida (FREUD 1969: 81-82).

Sendo assim, optando por essa "luta pela vida", o professor quer logo se eximir, abandonando seu animal que, em clara oposição a ele, naturalmente não sofre com essa divisão da personalidade, com a desintegração do ego resultante dessa tentativa humana de adaptação a padrões de civilização demasiado elevados para o mecanismo intelectual e psíquico. O sujeito, em consequência disso, desenvolve uma propensão à maldade que se manifesta como forma de vingança contra esse ajustamento precário às exigências da civilização.

$\mathrm{O}$ resultado imediato que adviria deste embate resume-se em compreender a inibição - encabeçada pela civilização - desses instintos no indivíduo. Sua agressividade constitutiva é, assim, introjetada, dirigindo-se ao seu próprio ego, isto é, retorna ao lugar de onde proveio. Uma vez internalizada, funciona como um superego em termos mais familiares, como "consciência" - que irá impor ao ego a mesma agressividade que este gostaria de dirigir a outros indivíduos. Da tensão entre essas duas instâncias psíquicas surge o sentimento de culpa, que desencadeia uma necessidade excruciante de punição (FREUD 1969: 84). O professor, atormentado por esse conflito, age do modo que lhe parece ser a solução para essa angústia lancinante:

Mas só tu e eu sabemos que te abandonei porque eras a possibilidade constante do crime que eu nunca tinha cometido. A possibilidade de eu pecar o que, no disfarçado de meus olhos, já era pecado. Então pequei logo para ser logo culpado. E este crime substitui o crime maior que eu não tive coragem de cometer (125) 
A culpa seria assim um elemento constitutivo, soberano no psiquismo do ser humano, cuja causa, entretanto, não lhe é evidente. A princípio, tememos fazer algo mau pelo medo de sermos descobertos por uma autoridade - desde que não haja essa possibilidade agimos de maneira má pelo simples prazer que isso nos causa. No entanto, essa "autoridade" é posteriormente internalizada pelo indivíduo - como superego -; assim, sentimo-nos culpados não apenas quando sabemos termos feito algo mau, mas quando reconhecemos em nós a simples intenção de fazê-lo, já que "a distinção entre fazer algo mau e desejar fazê-lo desaparece inteiramente, pois nada pode ser escondido do superego, sequer os pensamentos.” (FREUD 1969: 84).

Desse modo, essa autoridade interna - representando os rígidos códigos morais instituídos - parece exercer uma enorme aflição no professor, despertando nele a necessidade de punição. No excerto acima, fica claro que o desconhecimento do professor em relação à procedência desse tormento - do "pecado original" -; portanto, escolhe enjeitar o cachorro, crendo ser este um modo de justificar a culpa, atribuir-lhe um sentido, o que, entretanto, racionalmente, não possui justificativa - "Há tantas formas de ser culpado e de perder-se para sempre e de se trair e de não enfrentar. Eu escolhi a de ferir um cão" (124).

A despeito dessa tentativa, o desamparo do professor não encontra resolução. $O$ abandono do bicho - que nada mais é que a renúncia de seus instintos em respeito a um “agente paternal" (FREUD 1969: 84) desconhecido/ "estranho" -, não pode ser punido. No momento em que sua consciência exigia apenas a renúncia dos instintos, por medo de uma agressão ou perda de amor desse "pai” que o protege de uma agressão punitiva, o que importava era não ser descoberto. Porém, numa segunda etapa desse desenrolar psíquico, a intenção de fazer algo, ao se igualar ao ato em si, suscita no professor não apenas o sentimento de culpa, mas também a necessidade renitente de punição.

Contudo, "só agora ele parecia compreender, em toda sua gélida plenitude, que fizera com o cão algo realmente impune e para sempre. Pois não haviam inventado castigo para os grandes crimes disfarçados e para as profundas traições." (124). A perfídia para consigo, pelo contrário, é fomentada e desejada pelo processo civilizatório - "este crime ninguém o condenava" (124), ele teria que rogar por acusações e punições.

O cão, com sua alegria dada e pura, desperta o homem para a consciência dessa mortificação, tornando consciente o inconsciente. O confronto estabelecido, assim, entre 
Barreto de Castro, T. A. - Pungente Vislumbre

humano e animal, permite ao professor entender, ou ao menos tanger - no momento de seus flashes rememorativos no alto da montanha -, o que lhe fora "tomado" pela escolha desse modo de "viver". Aquilo que um dia fora alegria, compreensão de si, tornou-se estranho, assustador e, assim, evitável - ficando relegado, desse modo, aos escombros profundos da mente.

Ao final, "como se não bastasse ainda, começou a descer as escarpas em direção ao seio de sua família" (125). O homem, assumindo sua culpa, e com isso, sua condição humana vulnerável e passível de erros, busca a redenção intelectual - em detrimento da instintiva - ao se dirigir novamente ao seu círculo social habitual, seu porto seguro.

Pode ser que o professor de matemática, ainda assim, saia à busca de um novo tempo, no qual essa primeira consciência de si, proveniente do impasse da constituição da alteridade, harmonize-se com as exigências civilizatórias. O conto, todavia, não tem o desfecho circunscrito a uma única possibilidade - nisso reside sua riqueza formal, aberta a diversas interpretações.

\section{Referências bibliográficas}

ARRUdA FiLho, Raul José Matos de. "O olhar insuficiente do professor de matemática." In: Anuário de Literatura (11). Florianópolis, 2003, 95-106.

Chevalier, Jean \& Gheerbrant, Alain. Dicionário de símbolos. Trad. de Vera da Costa e Silva et al. Rio de Janeiro: José Olympio, 2008.

FREUD, Sigmund. "O estranho". In: Uma criança é espancada e outros trabalhos. v.27. Imago, 1969.

O mal-estar na civilização. Trad. José Octávio de Aguiar Abreu. Rio de Janeiro: Imago, 1997.

KRISTEVA, Julia. Estrangeiros para nós mesmos. Rio de Janeiro. Rocco, 1994.

LISPECTOR, Clarice. Água Viva. Rio de Janeiro. Rocco, 1998. 1998. "Os desastres de Sofia.” In: Felicidade Clandestina. Rio de Janeiro, Rocco,

" "O crime do professor de matemática." In: Laços de família. Rio de Janeiro, Rocco, 2009.

MARTINS, Gilberto F. As vigas de um heroísmo vago (três estudos sobre A maçã no escuro). Dissertação de mestrado apresentada à FFLCH da USP. São Paulo, 1996.

Moser, Benjamin. Clarice, uma biografia. Trad. José Geraldo Couto. São Paulo, Cosac Nayfi, 2011.

QUEIROZ, Edilene F. “A trama do olhar". In: Latin-American Journal of Fundamental Psychopathology on Line 1, nov. 2005, 89-100. http://www.fundamentalpsychopathology.org (10/06/2012).

TAVARES, Braulio. Freud e o estranho: contos fantásticos do inconsciente. Rio de Janeiro, Casa da Palavra, 2007.

recebido em 01/08/12; aprovado em 18/10/12 